ORIGINAL ARTICLE / ARTIGO ORIGINAL

\title{
Entry of dengue virus serotypes and their geographic distribution in Brazilian federative units: a systematic review
}

\author{
Entrada e distribuição geográlica dos sorotipos do virus da dengue nas \\ unidades federativas brasileiras: uma revisão sistemática
}

\author{
Juliana Maria Trindade Bezerral (iD), Selma Costa de Sousa",III (D), Pedro Luiz Tauil' ${ }^{\text {ID }}$, \\ Mariângela Carneiro"li,v (D), David Soeiro Barbosa"II (D)
}

\begin{abstract}
Objective: To describe the entry of Dengue virus (DENV) serotypes in Brazil and its federative units. Methods: A systematic review of studies published between 1980 and 2018 in databases and in the gray literature was performed using descriptors related to the years of entry of the DENV serotypes. Additionally, experts and official sources of information (Brazilian Ministry of Health) were consulted. Results: From 100 publications selected for the systematic review, 26 addressed the entry of DENV serotypes in the North region of the country, 33 in the Northeast, 24 in the Southeast, 14 in the Central-West, and five in the South. DENV-1 and DENV-4 were introduced in the North region in 1981. DENV-2 was introduced in the Southeast in 1990. DENV-3 was introduced in the North in 1999. Conclusion: The rapid expansion of dengue throughout the Brazilian territory was verified from the second half of the 1980s, with the gradual entry of the four serotypes, which resulted in the emergence of epidemics of arbovirus, which are currently verified in the country. Considering the epidemiology of the disease, more information should be disseminated and published in the wide-ranging scientific literature for a better understanding of the spread and circulation of DENV serotypes.
\end{abstract} Keywords: Dengue. Dengue virus. Serogroup. Epidemiology. Systematic review.

'Biological Sciences Program, Universidade Estadual do Maranhão - Lago da Pedra (MA), Brazil.

"Department of Occupational Health Care, Universidade Federal de Minas Gerais - Belo Horizonte (MG), Brazil.

"'Laboratory of Epidemiology of Infectious and Parasitic Diseases, Department of Parasitology, Biological Sciences Institute, Universidade Federal de Minas Gerais - Belo Horizonte (MG), Brazil.

IvSchool of Medicine, Graduate Program in Tropical Medicine, Universidade de Brasília - Brasília (DF), Brazil.

vGraduate Program in Health Sciences, Infectious Disease and Tropical Medicine, Universidade Federal de Minas Gerais - Belo Horizonte (MG), Brazil.

Corresponding author: Juliana Maria Trindade Bezerra. Curso de Ciências Biológicas, Universidade Estadual do Maranhão. Avenida Roseana Sarney, s/n, Vila Rocha, CEP: 65715-000, Lago da Pedra, MA, Brazil. E-mail: julianabezerra@professor.uema.br Conflict of interests: nothing to declare - Financial support: none. 
RESUMO: Objetivo: Descreveu-se a entrada de sorotipos do vírus da Dengue (DENV) no Brasil e em suas unidades federativas. Métodos: Realizou-se uma revisão sistemática de estudos publicados entre 1980 e 2018 em bancos de dados e na literatura cinzenta, utilizando-se descritores relacionados aos anos de entrada dos sorotipos do DENV. Além disso, consultou-se especialistas e fontes oficiais de informação (Ministério da Saúde do Brasil). Resultados: Das 100 publicações selecionadas para a revisão sistemática, 26 abordaram a entrada de sorotipos de DENV na região Norte do país, 33 no Nordeste, 24 no Sudeste, 14 no Centro-Oeste e cinco no Sul. O DENV-1 e o DENV-4 foram introduzidos na região Norte em 1981. O DENV-2 foi introduzido no Sudeste em 1990. O DENV-3 foi introduzido no Norte em 1999. Conclusão: A rápida expansão da dengue por todo o território brasileiro foi verificada a partir da segunda metade dos anos de 1980, com a entrada gradativa dos quatro sorotipos, o que resultou no surgimento de epidemias da arbovirose, que são atualmente verificadas no país. Considerando a epidemiologia da doença, mais informações devem ser divulgadas e publicadas na literatura científica de amplo alcance, para melhor entendimento da propagação e circulação dos sorotipos de DENV.

Palavras-chave: Dengue. Vírus da dengue. Sorogrupo. Epidemiologia. Revisão sistemática.

\section{INTRODUCTION}

Dengue represents an important vector-borne disease worldwide due to its morbidity and impacts on public health ${ }^{1}$. In Brazil, the disease is currently the object of largest public health programs, which focus on Aedes aegypti control. This mosquito is adapted to reproduce in domestic and peridomestic environments, using different types of stagnant water containers $^{2}$. The wide dispersion of this vector has also caused epidemics of other arboviruses, such as Zika fever ${ }^{3}$ and Chikungunya fever ${ }^{4}$, which have been occurring since 2015 in different Brazilian federative units ${ }^{5-7}$.

The reasons underlying the spread of dengue in the tropics and subtropics of the globe are complex ${ }^{8,9}$. Ae. aegypti is found from Uruguay to the South of the United States of America, where dengue outbreaks have been reported in recent decades in countries such as Venezuela, Cuba, Paraguay, and Brazil. In addition, the countries of the Americas face the fact that social, economic and environmental conditions have simultaneously contributed to making dengue a health problem in their populations ${ }^{8,9}$.

Reports of dengue epidemics in Brazil have been described since 1846, in the states of São Paulo and Rio de Janeiro. However, the first citations of clinical cases of the disease in the scientific literature are from 1916 in the city of São Paulo ${ }^{10}$, and 1923 in Niterói ${ }^{11}$. In the years of 1953 and 1954, a serological survey carried out among individuals residing in the Brazilian Amazon identified antibodies of Dengue virus (DENV) serotypes DENV-1 and DENV-2, thus indicating that the virus may have formerly circulated in the region ${ }^{12}$.

The first dengue epidemic clinically and laboratory-confirmed in the country occurred in 1981 and 1982, in Boa Vista (state of Roraima) and was caused by serotypes DENV-1 and DENV-4 ${ }^{13}$. DENV-2 was introduced in Rio de Janeiro in 1990. Nine years later, in 1999, 
DENV-3 was introduced in the states of Amapá, Pará, Roraima, and Tocantins (data provided by the Brazilian Ministry of Health). In 2008, a new record of DENV-4 circulation was registered in the state of Amazonas ${ }^{14}$. Overall, in the last 20 years, the country experienced four major epidemics associated with different predominant viral serotypes: DENV-1 (1998), DENV-3 (2002), DENV-2 (2008), and DENV-4 (2010) ${ }^{15}$.

In $2019,1,544,987$ cases were notified, with an incidence of 735.2 cases $/ 100,000$ inhabitants $^{15}$. Despite the low mortality rate, the disease contributes to the loss of healthy years of life in Brazil, as it affects a large number of people, from all age groups, and can cause some degree of disability during the infection and lead to death, especially among children ${ }^{16,17}$.

Considering the several studies that show the circulation of DENV and also the relevance and magnitude of dengue in Brazil, the elaboration of a systematic review has become relevant. In addition, Brazil has proximity to other dengue endemic countries, which makes surveillance important in terms of knowledge of circulating virus serotypes. The present study aims to present a systematic review of the scientific literature on the entry of DENV serotypes in Brazil and its federative units over the years.

\section{METHODS}

\section{STUDY AREA}

Brazil is politically and administratively divided into 27 federative units (26 states and the Federal District) and 5,570 municipalities ${ }^{18}$. The 27 federative units are grouped into five geographic regions: North (seven states), Northeast (nine states), Central-West (three states and the Federal District), Southeast (four states), and South (three states) ${ }^{19}$.

\section{STUDY DESIGN}

This is a systematic review of the literature from different electronic databases, using descriptors associated with the year of entry of DENV serotypes and its circulation in Brazil and its 27 federative units. The search for and selection of the publications was performed in the second semester of 2019, with studies from 1980 to 2018.

The study was conducted following these steps: research in the electronic databases, research in the gray literature, consultation of experts from the Brazilian Ministry of Health, reading and analysis of the publications, and selection of publications for the final version of the systematic review.

The used electronic databases were:

- Scientific Electronic Library Online (SciELO);

- Virtual Health Library (VHL);

- U. S. National Library of Medicine (PubMed). 
The gray literature was surveyed on Google Scholar for additional publications with the aim of avoiding an inadequate or non-comprehensive selection including full-text publications only, which would reduce the representativeness of the studies identified or included $^{20}$. For the years for which data on the entry of DENV serotypes was missing, information was requested from specialists at the Brazilian Ministry of Health, who provided Microsoft Office Excel (Washington, USA) database spreadsheets with data recorded from 1999 to 2018.

\section{SEARCH STRATEGY}

The searches were conducted using descriptors cataloged in the Health Sciences Descriptor (DeCS) and in the Medical Subject Headings (MeSH), in Portuguese, English, Spanish, and French. Studies that contained these terms in the title or in the summary were selected. The Boolean operators "AND" and "OR" were used as well as quotation marks to facilitate the search of the manuscripts. In each of the databases (SciELO, VHL, and PubMed), combinations of terms, together or separately, were used in the four aforementioned languages: Dengue (similar terms: "Dengue fever," "Dengue virus infection," "Dengue hemorrhagic fever," "Dengue shock syndrome"), Dengue Virus (similar terms: "DENV," "Serotype," "Serotyping," "Serology Typing," "DENV-1," "DENV-2," "DENV3," "DENV-4," "Serotype 1," "Serotype 2," "Serotype 3," "Serotype 4," "Dengue virus detection," "Dengue virus isolation," "Dengue virus introduction”), Circulation (similar terms: "co-circulation," "viral circulation," "seroepidemiological study of dengue," "identification of serotypes of dengue," "first registration of Dengue virus," "first registration of Dengue virus serotype").

The systematic search was independently reproduced by two researchers under the guidance of a librarian from Universidade Federal de Minas Gerais. The systematic review was recorded in the International Prospective Register of Systematic Reviews, registration number CRD42018095017 ${ }^{21}$. The research followed PRISMA guidelines for systematic review ${ }^{22}$.

\section{SELECTION AND ANALYSIS OF PUBLICATIONS}

Studies were selected based on a designed form including information regarding: federative unit where the study took place, author and year of publication, journal of publication, study type, and main results. The inclusion criteria were studies in the format of original articles, review articles, brief communications, short communications, case reports, research notes, editorials, abstracts, updates, official data (bulletins, epidemiological reports, and manuals from the Brazilian Ministry of Health), technical notes, dissertations, and theses, published between 1980 and 2018, in international or national journals or in electronic pages available for access, in English, Portuguese, Spanish, or French, and indexed in one 
of the aforementioned bases. Only publications containing, in any part of the text, data regarding the year of entry and/ or circulation of DENV in Brazil and its 27 federative units were selected for the systematic review. It should be emphasized that the information was used both if the authors were responsible for the first publication on the DENV introduction and if they only cited it (for example, if the information was in the "Introduction" or "Discussion" sections). All the studies that did not meet the inclusion criteria were excluded from the study. Each methodological step of the systematic review was independently performed by two researchers, and the results were compared. Cases of disagreement were resolved by a third researcher, who was called to help reach a consensus on the inclusion or exclusion of studies.

The results are described in tables, graphs, and maps prepared using the Microsoft Office Excel and Microsoft Office Word software version 2010 (USA), GraphPad Prism version 5.0 (La Jolla, California, USA), and QGIS version 2.18 (Las Palmas, Spain), respectively.

\section{RESULTS}

Of the total of 2,048 studies resulting from the initial search, 37 studies were excluded because they were duplicated; and 1,860, for being unrelated to the topic of the review. Subsequently, 16 studies were excluded after reading the abstract and 35 after reading the full text because they did not present the information sought. Thus, 68 papers were selected for the present review based on the search strategy adopted. Additionally, 32 studies were selected from the gray literature. Therefore, the present systematic review was organized based on a total of 100 studies, considering those selected from the search strategy and those resulting from the gray literature. The results obtained from each step of the selection of all the evaluated studies are presented in the study flowchart (Figure 1).

From the 100 selected publications, 26 addressed the entry of DENV serotypes in federative units of the North region of Brazil (two in Acre, none in Amapá, ten in Amazonas, four in Pará, six in Roraima, three in Rondônia, and one in Tocantins). Thirty-tree addressed the Northeast region (two in Alagoas, seven in Bahia, eight in Ceará, four in Maranhão, three in Pernambuco, three in Piauí, five in Rio Grande do Norte, and one in Sergipe). The Southeast region was the subject of 24 studies (two in Espírito Santo, five in Minas Gerais, 13 in Rio de Janeiro, and four in São Paulo). Fourteen publications addressed the Central-West region (two in the Federal District, two in Goiás, six in Mato Grosso, and four in Mato Grosso do Sul). Lastly, the entry of DENV serotypes in the South region was explored by five studies (two in Paraná, none in Santa Catarina, and three in Rio Grande do Sul). One of the selected articles included information about three states (Pará, Roraima, and Bahia) and is, therefore, cited three times. Nevertheless, it was considered as a single publication in the total number of 100 (Supplementary Table 1).

The consultation of experts allowed to fill in the gaps of missing information regarding the years of entry of specific serotypes: all serotypes in Amapá, DENV-3 in Pará, DENV-2 and 
DENV-3 in Roraima, DENV-4 in Rondônia, and DENV-1 and DENV-4 in Tocantins (North region); DENV-3 in Alagoas, all serotypes in Paraíba and Sergipe, and DENV-1 in Piauí and Rio Grande do Norte (Northeast region); DENV-4 in the Federal District and Goiás, DENV-1 in Mato Grosso, and DENV-3 in Mato Grosso do Sul (Central-West region); DENV-1 and DENV-3 in Paraná and all serotypes in Santa Catarina (South region) (Supplementary Table 1).

Serotypes DENV-1 and DENV-4 were introduced in the country in 1981; DENV-2, in 1990; and DENV-3, in 2001. Table 1 presents the year of entry of the four dengue serotypes in the country by region and federative unit.

When grouping the authors' observations on the entry of DENV serotypes into periods of four and five years (Figure 2), it was observed that 14 years after the entry of the serotypes DENV-1 and DENV-4 in the state of Roraima (1981), in the period between 1995 and 1999, serotypes DENV-1 and DENV-2 were concurrently introduced in the states of Amazonas, Espírito Santo, Minas Gerais, and Piauí; serotypes DENV-2 and DENV-3 were introduced in Roraima; and DENV-1, DENV-2, and DENV-3 were identified for the first time in the state of Pará. In the period from 2000 to 2004, DENV-2 and DENV-3 were introduced in the states of Maranhão and Santa Catarina, whereas Acre, Paraíba, and Sergipe stood out with the concomitant introduction of serotypes DENV-1, DENV-2, and DENV-3. Between 2010 and 2013, three serotypes were again introduced in Rio Grande do Sul: DENV-1, DENV-2, and DENV-4 (Figure 2 and Table 1).

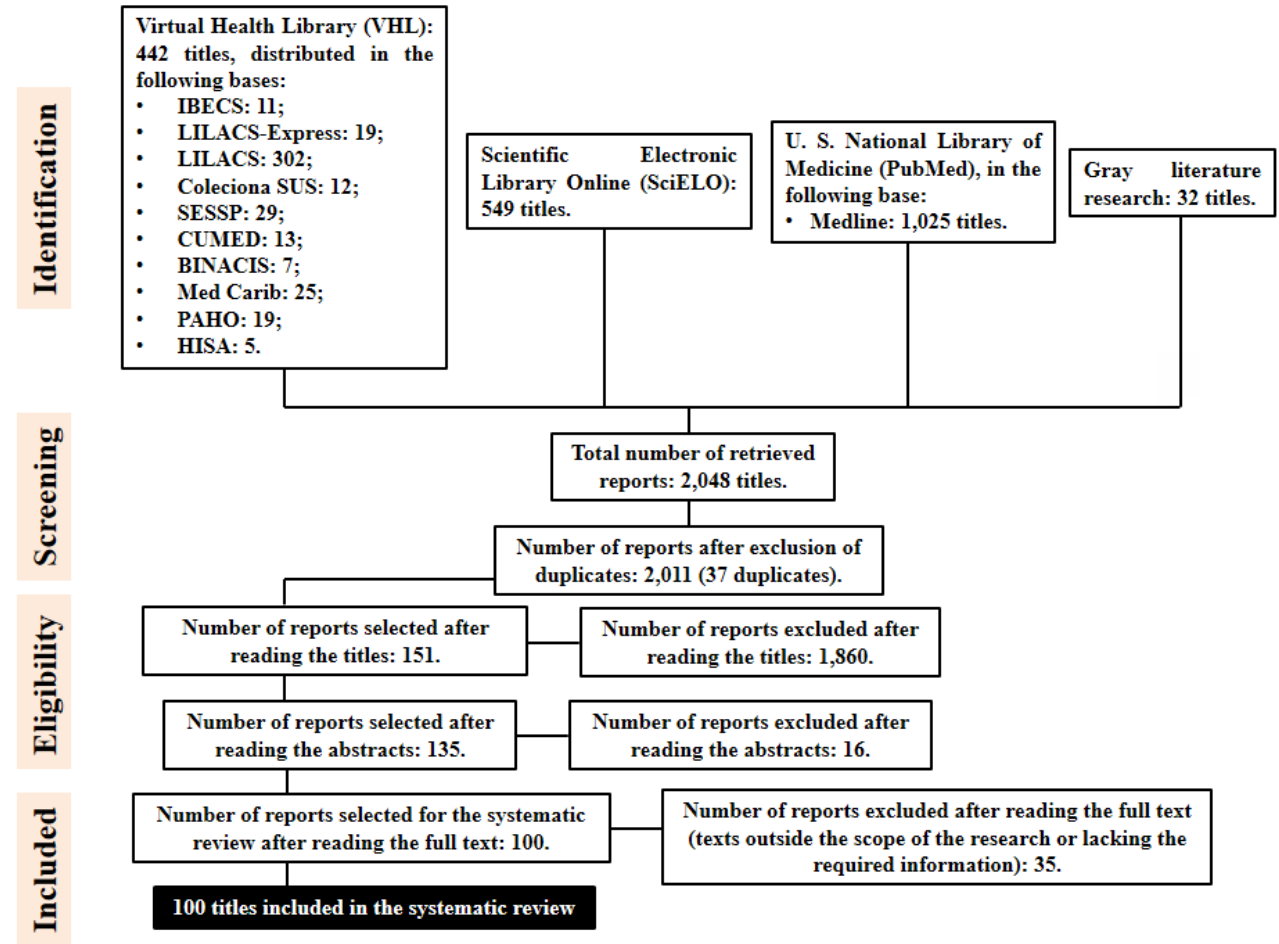

Figure 1. Flowchart of the systematic review of studies on the introduction of Dengue virus (DENV) serotypes in Brazil and its federative units published between 1980 and 2018. 
Table 1. Years of entry of Dengue virus serotypes in Brazil by federative unit, according to the publications from 1980 to 2018 selected for this systematic review.

\begin{tabular}{|c|c|c|c|c|}
\hline \multirow{2}{*}{ Regions and federative units } & \multicolumn{4}{|c|}{ Year of entry of each serotype } \\
\hline & DENV-1 & DENV-2 & DENV-3 & DENV-4 \\
\hline \multicolumn{5}{|l|}{ North } \\
\hline Acre & 2000 & 2000 & 2004 & 2012 \\
\hline Amapá & $2001^{a}$ & $2006^{a}$ & $1999^{a}$ & $2012^{b}$ \\
\hline Amazonas & 1998 & 1998 & 2002 & 2008 \\
\hline Pará & 1995 & 1997 & $1999 a$ & 2010 \\
\hline Roraima & 1981 & $1999 a$ & $1999 a$ & 1981 \\
\hline Rondônia & 1999 & 2006 & 2004 & $2013^{b}$ \\
\hline Tocantins & $2000^{a}$ & 1991 & $1999^{a}$ & $2011^{b}$ \\
\hline \multicolumn{5}{|l|}{ Northeast } \\
\hline Alagoas & 1986 & 1995 & $2000^{a}$ & $2012^{b}$ \\
\hline Bahia & 1987 & 1994 & 2002 & 2011 \\
\hline Ceará & 1986 & 1994 & 2002 & 2011 \\
\hline Maranhão & 1994 & 2001 & 2002 & 2011 \\
\hline Paraíba & $2001^{a}$ & $2001^{a}$ & $2002^{a}$ & $2012^{b}$ \\
\hline Pernambuco & 1987 & 1998 & 2002 & $2011^{b}$ \\
\hline Piauí & $1999^{a}$ & 1995 & 2002 & $2011^{b}$ \\
\hline Rio Grande do Norte & $1999^{a}$ & 2008 & 2002 & 2011 \\
\hline Sergipe & $2000^{a}$ & $2001^{a}$ & $2002^{a}$ & $2012^{b}$ \\
\hline \multicolumn{5}{|l|}{ Southeast } \\
\hline Espírito Santo & 1996 & 1995 & 2003 & 2013 \\
\hline Minas Gerais & 1996 & 1998 & 2002 & 2011 \\
\hline Rio de Janeiro & 1986 & 1990 & 2001 & 2011 \\
\hline São Paulo & 1987 & 1996 & 2002 & 2011 \\
\hline \multicolumn{5}{|l|}{ Central-West } \\
\hline Federal District & 1998 & 1991 & 2003 & $2012^{b}$ \\
\hline Goiás & 1994 & 1999 & 2002 & $2011^{\mathrm{b}}$ \\
\hline Mato Grosso & $2000^{a}$ & 1995 & 2001 & 2011 \\
\hline Mato Grosso do Sul & 1987 & 1996 & $2000^{a}$ & 2012 \\
\hline \multicolumn{5}{|l|}{ South } \\
\hline Paraná & $2001^{a}$ & 1995 & $2000^{a}$ & 2013 \\
\hline Rio Grande do Sul & 2010 & 2010 & 2007 & 2011 \\
\hline Santa Catarina & 1999a & $2003^{a}$ & $2002^{\mathrm{a}}$ & $N S I^{b}$ \\
\hline
\end{tabular}

DENV: Dengue virus; NSI: no serotype introduction; ain the consultation of the experts, data on the years of entry were provided from 1999 onward; therefore, 1999 was considered the year of entry of the serotypes DENV-1, DENV-2, and DENV-3; bfor serotype DENV-4, the information about the year of entry provided by the experts is correct, and this serotype started circulating in the country again in 2008 and spread to all states except Santa Catarina. 


\section{DISCUSSION}

Our systematic review provides an overview of the entry of the four DENV serotypes in Brazil and its federative units, from 1980 to 2018. The 100 publications evaluated refer to 25 of the 27 federative units distributed in the five Brazilian regions. Further information on the years of entry for the four DENV serotypes was obtained by consulting experts. Since the first laboratory-confirmed epidemic caused by serotypes DENV-1 and DENV-4 in 1981, there was a delay of nine years until the entry of serotype DENV-2 in 1990, and another nine years until the entry of serotype DENV-3 in 1999. Then, 27 years later, the serotype DENV-4 started circulating again in the country in 2008. As the literature refers to studies on dengue epidemics in Brazil in $1846^{10,11}$ and in 1953 and $1954^{12}$, the authors believe that some of these serotypes may have been introduced in the country before the years presented in this study. However, according to the search criteria established in this systematic review, only published studies that provided proven scientific evidence of the years of entry were pooled.

Regarding the temporal distribution of dengue in Brazil, two distinct periods were observed. The number of cases reported did not exceed 100,000 from 1980 to 1990. After this period, the numbers gradually increased and reached more than one million
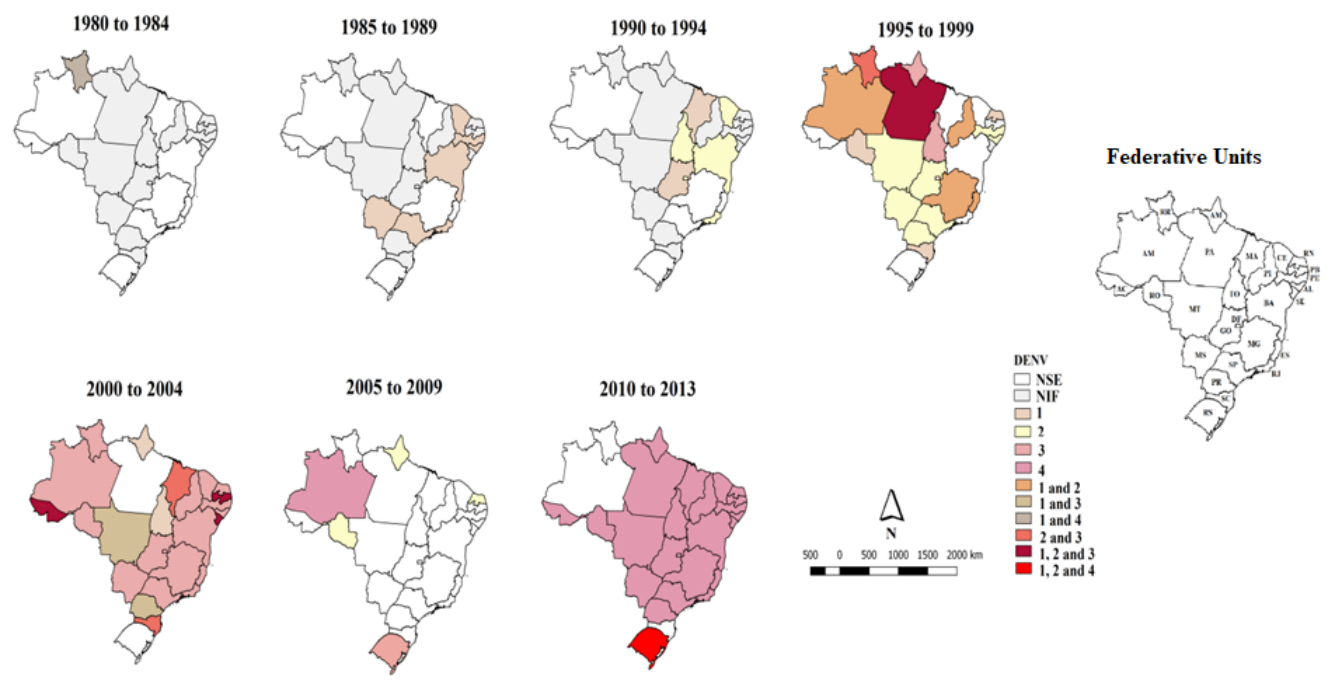

NSE: no serotype entry; NIF: no information found; 1: DENV-1; 2: DENV-2; 3: DENV-3; 4: DENV-4; 1 and 2: DENV-1 and DENV-2; 1 and 3: DENV-1 and DENV-3; 1 and 4: DENV-1 and DENV-4; 2 and 3: DENV-2 and DENV-3; 1, 2 and 3: DENV-1, DENV-2, and DENV-3; 1, 2 and 4: DENV-1, DENV-2, and DENV-4.

Figure 2. Entry of Dengue virus serotypes in Brazil by federative unit and considering periods of four (2010 to 2013) and five years (1980 to 1984, 1985 to 1989, 1990 to 1994, 1995 to 1999 , 2000 to 2004 , and 2005 to 2009), according to the publications between 1980 and 2018 selected for this systematic review. 
in the last years ${ }^{7,122,123}$. This initial phase was characterized by localized and sporadic epidemic waves in urban centers, with the introduction of serotypes DENV-1, DENV2 , and DENV-4 ${ }^{13,88}$. The Brazilian territory is characterized by the occurrence of dengue epidemics every two or three years. Since 1991, dengue fever has shown a seasonal pattern with peaks of notable epidemics in 1998 (507,715 cases), 2002 (696,472 cases), 2010 (1,011,548 cases), 2013 (1,452,489 cases), 2015 (1,688,688 cases), and 2016 (1,500,535 cases $)^{124}$. This is due to the introduction of DENV-3, the resurgence of DENV-4, and the concomitant circulation of the four serotypes ${ }^{7,89,125}$.

Considering these peaks of epidemics, over the years, some Brazilian states have shown the introduction of two or more DENV serotypes in short periods of time. In the interval between 1995 and 1999, states of different regions of the country showed the introduction of serotypes DENV-1 and DENV-2 (Amazonas - North region; Piauí - Northeast region; and Espírito Santo and Minas Gerais - Southeast region), serotypes DENV-2 and DENV-3 (Roraima - North region), and serotypes DENV-1, DENV-2, and DENV-3 (Pará - North region). A similar occurrence was observed between 2000 and 2004, when serotypes DENV-2 and DENV-3 emerged in Maranhão (Northeast region) and Santa Catarina (South region), serotypes DENV-1 and DENV-3 were introduced in Mato Grosso (Central-West region) and Paraná (South region), and serotypes DENV-1, DENV-2, and DENV-3 were found circulating in Acre (North region), Paraíba, and Sergipe (Northeast region). The state of Rio Grande do Sul (South region) also showed the introduction of serotypes DENV-1, DENV-2, and DENV-4 in an interval of four years (between 2010 and 2013). The entry and transmission of DENV serotypes in different regions of the country can be explained by the number of municipalities infested with Ae. aegypti mosquitoes, the population mobility, and the rapid and unplanned urbanization that began in the $1990 \mathrm{~s}^{125-129}$.

In addition, dengue epidemics have occurred more frequently in the Northeast region of the country, with a large number of serious cases and reported deaths. DENV-1 and DENV-2 showed different temporal patterns of introduction in nine states of the Northeast. DENV-1 was identified in 1986 and 1987 in the states of Alagoas $^{47}$, Bahia ${ }^{49-52}$, Ceará ${ }^{55-61}$, and Pernambuco ${ }^{68}$, whereas DENV-2 was introduced in 1994 and 1995 in Alagoas ${ }^{47}$, Bahia ${ }^{49-52}$, Ceará ${ }^{55,57-61}$, and Piauí ${ }^{70}$. On the other hand, DENV-3 and DENV-4 were introduced around the same years in all federative units of this region, with concomitant occurrences in all states.

In the Southeast region, the state of Rio de Janeiro emerged with the highest number of dengue reports in 1986, when DENV-1 (33,568 cases) was introduced in this federative unit ${ }^{122,123}$. Since then, the state has always presented annual records of the disease $^{124}$. It should be noted that the first case of DENV-2 identified in 1990 also occurred in this state ${ }^{89}$.

Moreover, among all the regions of the country, the Southeast presented the most complete information in the literature databases regarding the circulation of the four 
DENV serotypes. It was noted that the years of introduction of DENV-1 were very similar in Rio de Janeiro (1986) $)^{86,87}$ and São Paulo $(1987)^{99}$. Similarly, DENV-2 was introduced in São Paulo in $1996^{99}$ and in Minas Gerais in $1998^{81}$. The introduction of DENV-3 occurred in sequential years, beginning in 2001 in Rio de Janeiro ${ }^{92}$, in 2002 in São Paulo ${ }^{101}$ and Minas Gerais ${ }^{81}$, and in 2003 in Espírito Santo ${ }^{79}$. In 2011, DENV-4 reached the states of Rio de Janeiro ${ }^{95}$, Minas Gerais ${ }^{84}$, and São Paulo ${ }^{100}$, finally reaching Espírito Santo in $2013^{80}$.

In the Central-West region, the entry of DENV-1 was verified in 1987 in the state of Mato Grosso do Sul ${ }^{114}$, and four years later the introduction of serotype DENV-2 was reported in the Federal District ${ }^{103}$. After a period of nine years, DENV-3 was registered in the region, particularly in the state of Mato Grosso ${ }^{108}$. Following the dynamics reported in other regions, DENV-4 was introduced in the states of Goiás (according to experts' consultation) and Mato Grosso ${ }^{112}$ in 2011.

In the South, the entry of dengue followed a different pattern, with none of the serotypes being introduced in similar years in the three states. Although dengue has been reported in the Brazilian territory since the early 1980s, dengue fever was reported in the South region years later. DENV-2 was the first serotype to circulate in the region, introduced in the state of Paraná in 1995. DENV-1 was introduced in Santa Catarina in 1999, whereas DENV-3 was introduced in Paraná in 2000 (according to experts' consultation) and DENV-4 reached Rio Grande do Sul in $2011^{121}$. Until the conclusion of this research, no DENV-4 reports had been observed in Santa Catarina, thus indicating that this serotype did not reach the state yet (according to experts' consultation).

The wide climatic variability of Brazil is explained by the size of the territory, the extent of the coastline, altitude variation, and mainly by the presence of different air masses that modify the temperature and humidity conditions of the five regions ${ }^{130}$. These conditions favor the proliferation and maintenance of the country's primary dengue vector, Ae. aegypti $i^{47,131}$.

The states of the North are located in the area of the Legal Amazon and are mostly covered by tropical forest. Environmental factors, such as high temperatures and high humidity throughout the year and an extended rainy season, along with social elements, provide the ideal conditions for the proliferation of vectors and the consequent spread of diseases such as dengue ${ }^{26,63}$.

The Northeast is the poorest region of the country, and most of its states are situated in a semi-arid area, with sparse rains and poor sociodemographic conditions. In addition, these states suffer from limitations on water supply, high temperatures during most of the year, and present other environmental and ecological conditions that make them vulnerable to the introduction, reintroduction, or maintenance of the circulation of DENV serotypes ${ }^{64,127}$.

In the Southeast and Central-West regions, besides the meteorological conditions that may favor the vector, other factors, such as transport, tourism, sanitary conditions, and aspects related to population immunity, can favor the spread of the virus ${ }^{104,105,107}$. 
The Southeast is the most developed and populous region of the country, whereas the Central-West is an area of agricultural-based economy on the southern border of the Amazon ${ }^{108,112,115,116 .}$

The South is characterized by a moderate climate, which is colder than the rest of the country. Therefore, for many years, except for the state of Paraná, the region was spared of dengue epidemics ${ }^{120,121}$. Moreover, the incidence of autochthonous dengue cases is mainly seasonal: it increases between December and April, when conditions are favorable to the development of the vector ${ }^{120,131}$.

Overall, the present systematic review included important data. Although some epidemiological information on the introduction of DENV serotypes in a few federative units of Brazil was lacking, the performed literature research was as embraceable as possible and the selection of sources aimed at identifying all the relevant data. Nevertheless, this analysis has its limitations. Considering that the authors were only able to review the published data found by their search techniques, it is worth mentioning that isolated reports from some federative units may have escaped the author's attention and that other findings, mainly from the gray literature, are still lacking a more prominent place in the literature of the electronic databases.

Moreover, some publications of certain federative units reported the occurrence of dengue cases but failed to mention the viral serotype responsible for that outbreak or epidemic. Some authors report that laboratory support consisting of both serological analysis and viral isolation is considered the cornerstone of active dengue surveillance, particularly due to the need for precocious diagnostic confirmation of the first suspected cases in a non-endemic area.

In conclusion, dengue epidemics in Brazil have been attributed to the dissemination of different DENV serotypes, the permanent migratory flow of viral travelers, and the increase of vector infestation throughout the territory. In addition, urbanization probably had the greatest impact on increasing the occurrence of dengue within the country. Furthermore, continuous epidemiological surveillance is essential for the detection of new DENV lineages and for better understanding the regional patterns of dissemination of these viruses.

\section{ACKNOWLEDGEMENTS}

The authors thank Mr. Gesner Xavier, a librarian from Universidade Federal de Minas Gerais, for his support during the definition of the descriptors and the search strategies. The authors are also grateful to the technicians at the Brazilian Ministry of Health, especially Livia Carla Vinhal Frutuoso and Amanda Coutinho de Souza, for providing complementary information regarding the years of entry of Dengue virus serotypes in the Brazilian federative units, which were unavailable or missing during the search strategies adopted in this systematic review. 


\section{REFERENCES}

1. World Health Organization. Dengue and severe dengue [Internet]. Geneva: World Health Organization; 2018 [cited on July 15, 2018]. Available from: http:/ / www. who.int/denguecontrol/disease/en/

2. Powell JR, Tabachnick WJ. History of domestication and spread of Aedes aegypti - a review. Mem Inst Oswaldo Cruz 2013; 108(Suppl. 1): 11-7. https: / / doi. org/10.1590/0074-0276130395

3. Possas C. Zika: what we do and do not know based on the experiences of Brazil. Epidemiol Health 2016; 38: e2016023. https: / / doi.org/10.4178/ epih.e2016023

4. Conteville LC, Zanella L, Marín MA, Filippis AM, Nogueira RM, Vicente AC, et al. Phylogenetic analyses of chikungunya virus among travelers in Rio de Janeiro, Brazil, 2014-2015. Mem Inst Oswaldo Cruz 2016; 111(5): 347-48. https: / / doi.org/10.1590/0074-02760160004

5. Brasil. Ministério da Saúde. Boletim epidemiológico [Internet]. Brasil: Ministério da Saúde; 2015 [cited on Mar. 5, 2018]. Available from: http://portalsaude. saude.gov.br/images/pdf/2015/ outubro/29/2015035---Dengue-SE-40---29.10.15.pdf

6. Brasil. Ministério da Saúde. Monitoramento dos casos de microcefalia no Brasil até a Semana Epidemiológica 47 [Internet]. Brasil: Ministério da Saúde; 2015 [cited on Mar. 7, 2018]. Available from: http:/ / portalsaude. saude.gov.br/images/pdf/2015/novembro/30/coesmicrocefalias---informe-epidemiol--gico---se-47.pdf

7. Brasil. Ministério da Saúde. Boletim Epidemiológico. Monitoramento dos casos de dengue, febre de chikungunya e febre pelo vírus Zika até a Semana Epidemiológica 8 [Internet]. Brasil: Ministério da Saúde; 2016 [cited on Mar. 10, 2018]. Available from: http://portalsaude.saude.gov.br/images/pdf/2016/ marco/29/2016-011-boletim-epi-dcz-se8.pdf

8. San MartínJL, Brathwaite O, Zambrano B, SolórzanoJO, Bouckenooghe A, Dayan GH, et al. The epidemiology of dengue in the Americas over the last three decades: a worrisome reality. Am J Trop Med Hyg 2010; 82(1): 128-35. https: / / doi.org/10.4269/ajtmh.2010.09-0346

9. Ramos-Castañeda J, Barreto dos Santos F, MartínezVega R, Galvão de Araujo JM, Joint G, Sarti E. Dengue in Latin America: Systematic Review of Molecular Epidemiological Trends. PLoS Negl Trop Dis 2017; 11(1): e0005224. https:// doi.org/10.1371/journal. pntd.0005224

10. Meira R. "Urucubaca” gripe ou dengue? Dengue. In: Clínica médica, editor. São Paulo: Gráfica O Estado de São Paulo; 1916. p. 273-285.

11. Pedro A. O dengue em Nictheroy. O Brazil Médico 1923; 1: 174-7.
12. Causey OR, Theiler M. Virus antibody survey on sera of residents of the Amazon valley in Brazil. Mem Inst Evandro Chagas Arbovírus 1958; 7: 75-7.

13. Osanai CH, Travassos-da-Rosa APA, Amaral S, Passos ACD, Tauil PL. Surto de Dengue em Boa Vista, Roraima. Rev Inst Med Trop São Paulo 1983; 25(1): 53.

14. Brasil. Ministério da Saúde. Secretaria de Vigilância em Saúde. Diretoria Técnica de Gestão. Dengue: diagnóstico e manejo clínico - adulto e criança. $4^{\mathrm{a}}$ ed. Brasília: Ministério da Saúde; 2011.

15. Brasil. Ministério da Saúde. Secretaria de Vigilância em Saúde. Boletim Epidemiológico. Monitoramento dos casos de arboviroses urbanas transmitidas pelo Aedes (dengue, chikungunya e Zika), Semanas Epidemiológicas 01 a 52 de 2019 [Internet]. Brasília: Ministério da Saúde; 2020 [cited on Mar. 17, 2020]. Available from: http:/ / portalarquivos2.saude.gov.br/ images/pdf/2020/janeiro/20/Boletim-epidemiologicoSVS-02-1-.pdf

16. Araújo VEM, Bezerra JMT, Amâncio FF, Passos VMA, Carneiro M. Increase in the burden of dengue in Brazil and federated units, 2000 and 2015: analysis of the Global Burden of Disease Study 2015. Rev Bras Epidemiol 2017; 20(Suppl. 1): 205-16. https:// doi. org/10.1590/1980-5497201700050017

17. Fares RC, Souza KP, Añez G, Rios M. Epidemiological Scenario of Dengue in Brazil. BioMed Res Int 2015; 2015: 321873. https: / / doi. org / 10.1155/2015/321873

18. Instituto Brasileiro de Geografia e Estatística. Projeção da população do Brasil e das Unidades da Federação [Internet]. 2018 [cited on Apr. 20, 2018]. Available from: https: / /www.ibge.gov.br/apps/populacao/ projecao/

19. Instituto Brasileiro de Geografia e Estatística. Divisões Regionais do Brasil [Internet]. Brasil: Instituto Brasileiro de Geografia e Estatística; 2017 [cited on Apr. 19, 2018]. Available from: https:// www.ibge.gov.br/geociencias-novoportal/cartas-emapas/redes-geograficas / 15778-divisoes-regionaisdo-brasil.html

20. Lockwood C, Geum E. Systematic reviews: Guidelines, tools and checklists for authors. Nurs Health Sci 2017; 19(3): 273-7. https:// doi.org/10.1111/nhs. 12353

21. International Prospective Register of Systematic Reviews. How to register [Internet]. International Prospective Register of Systematic Reviews; 2018 [cited on Oct. 20, 2018]. Available from: https: / / www. crd.york.ac.uk/prospero/\#aboutregpage 
22. Preferred Reporting Items for Systematic Reviews and Meta-Analyses. Standards for Systematic Reviews [Internet]. Preferred Reporting Items for Systematic Reviews and Meta-Analyses; 2018 [cited on Oct. 20, 2018]. Available from: http://www.nationalacademies.org/ hmd/Reports / 2011 / Finding-What-Works-in-HealthCare-Standards-for-Systematic-Reviews/Standards.aspx

23. Guimarães MH, Vasconcelos PFC, Nunes MRT, Rodrigues SG, Tanajura D, Tavares-Neto J, et al. Inquérito soroepidemiológico de dengue em dois municípios do Estado do Acre, fronteira Brasil-Bolívia. Rev Ciên Med Biol 2006; 5(1): 13-20. https:/ / doi. org/10.9771/cmbio.v5i1.4566

24. Feitoza HAC, Koifman S, Koifman RJ, Saraceni V. Dengue infection during pregnancy and adverse maternal, fetal, and infant health outcomes in Rio Branco, Acre State, Brazil, 2007-2012. Cad Saúde Pública 2017; 33(5): e00178915. https:// doi. org/10.1590/0102-311x00178915

25. Bastos MS. Perfil soroepidemiológico do dengue diagnosticado na Fundação de Medicina Tropical do Amazonas (1998-2001) [dissertation]. Manaus: Universidade Federal do Amazonas; 2004.

26. Pinheiro VCS, Tadei WP, Barros PMSS, Vasconcelos PFC, Cruz ACR. Detection of dengue virus serotype 3 by reverse transcription polymerase chain reaction in Aedes aegypti (Diptera, Culicidae) captured in Manaus, Amazonas. Mem Inst Oswaldo Cruz 2005; 100(8): 8339. https: / / doi.org/10.1590/S0074-02762005000800003

27. Figueiredo RMP. Caracterização molecular e epidemiológica dos vírus dengue no Estado do Amazonas, Brasil [thesis]. Manaus: Universidade Federal do Amazonas; 2008.

28. Costa CA, Santos IGC, Barbosa MG. Detecção e tipagem de vírus dengue em Aedes aegypti (Diptera: Culicidae) na Cidade de Manaus, Estado do Amazonas. Rev Soc Bras Med Trop 2009; 42(6): 677-81. https: / / doi.org/10.1590/S0037-86822009000600013

29. Rocha LA, Tauil PL. Dengue em criança: aspectos clínicos e epidemiológicos, Manaus, Estado do Amazonas, no período de 2006 e 2007. Rev Soc Bras Med Trop 2009; 42(1): 18-22. https: / / doi.org/10.1590/ S0037-86822009000100005

30. Costa CA, Façanha GP. Sorotipos virais de dengue identificados em crianças de Manaus, Estado do Amazonas, 2008. Rev Soc Bras Med Trop 2011; 44(2): 24951. https: / doi.org/10.1590/S0037-86822011000200024

31. Bastos MS, Figueiredo RMP, Ramasawmy R, Itapirema E, Gimaque JBL, Santos LO, et al. Simultaneous circulation of all four dengue serotypes in Manaus, State of Amazonas, Brazil in 2011. Rev Soc Bras Med Trop 2012; 45(3): 393-94. https: / / doi.org/10.1590/ S0037-86822012000300022
32. Figueiredo RMP, Mourão MPG, Abi-Abib YEC, Oliveira CM, Roque R, Azara T, et al. Identification of dengue viruses in naturally infected Aedes aegypti females captured with BioGents (BG)-Sentinel traps in Manaus, Amazonas, Brazil. Rev Soc Bras Med Trop 2013; 46(2): 221-2. https: / / doi.org/10.1590/0037-8682-1096-2013

33. Mourão MPG, Bastos MS, Figueiredo RMP, Gimaque JBL, Alves VCR, Saraiva MGG, et al. Arboviral diseases in the Western Brazilian Amazon: a perspective and analysis from a tertiary health \& research center in Manaus, State of Amazonas. Rev Soc Bras Med Trop 2015; 48(Suppl. 1): 20-6. https: / / doi.org/10.1590/0037-8682-0133-2013

34. Nascimento VA, Souza VC, Naveca FG. Complete genome of a dengue virus serotype 4 strain from Amazonas, Brazil. Mem Inst Oswaldo Cruz 2016; 111(2): 141-3. https: / / doi.org/10.1590/0074-02760150416

35. Rosa APAT, Vasconcelos PFC, Travassos da Rosa ES, Rodrigues SG, Mondet B, Cruz ACR, et al. Dengue epidemic in Belém, Pará, Brazil, 1996-97. Emerg Infect Dis 2000; 6(3): 298-301. https:// doi.org/10.3201/ eid0603.000311

36. Araújo TP, Rodrigues SG, Costa MIWA, Vasconcelos PFC, Travassos da Rosa APA. Diagnóstico sorológico de infecções por dengue e febre amarela em casos suspeitos no Estado do Pará, Brasil, 1999. Rev Soc Bras Med Trop 2002; 35(6): 579-84. https: / / doi.org/10.1590/ S0037-86822002000600006

37. Barros LPS, Igawa SES, Jocundo SY, Brito Junior LC. Análise crítica dos achados hematológicos e sorológicos de pacientes com suspeita de Dengue. Rev Bras Hematol Hemoter 2008; 30(5): 363-66. https:/ / doi. org/10.1590/S1516-84842008000500007

38. Nunes MRT, Faria NR, Vasconcelos HB, Medeiros DBA, Lima CPS, Carvalho VL, et al. Phylogeography of Dengue Virus Serotype 4, Brazil, 2010-2011. Emerg Infect Dis 2012; 18(11): 1858-64. https:/ / doi. org/10.3201/ eid1811.120217

39. Siqueira TCS, Acosta POA, Cardoso MN, Maito RM. Epidemias de dengue no estado de Roraima de 1999 a 2009: sorotipos circulantes e formas graves da doença. In: Resumos da $61^{\text {a }}$ Reunião Annual da SBPC; 2009 jul 12-17; Manaus, Brasil [Internet]. Manaus: UFAM; 2009 [cited on Oct. 26, 2019]. Available from: www.sbpcnet. org.br/livro/61ra/resumos/resumos/6360.htm

40. Naveca FG, Souza VC, Silva GAV, Maito RM, Granja F, Siqueira T, et al. Complete Genome Sequence of a Dengue Virus Serotype 4 Strain Isolated in Roraima, Brazil. J Virol 2011; 86(3): 1897-8. https:/ / doi.org/10.1128/JVI.06731-11

41. Temporão JG, Penna GO, Carmo EH, Coelho GE, Azevedo RSS, Nunes MRT, et al. Dengue Virus Serotype 4, Roraima State, Brazil. Emerg Infect Dis 2011; 17(5): 938-40. https:// doi.org/10.3201/ eid1705.101681 
42. Acosta POA, Granja F, Meneses CA, Nascimento IAS, Sousa DD, Lima Júnior WP, et al. False-negative dengue cases in Roraima, Brazil: an approach regarding the high number of negative results by ns1 ag kits. Rev Inst Med Trop São Paulo 2014; 56(5): 447-50. https: / / doi.org/10.1590/S0036-46652014000500014

43. Vieira DS, Honda ER, Pereira SS, Bifano GS, Tada MS, Batista WC. Characterization of dengue virus serotype 1 in epidemics in Porto Velho, Rondônia, in 2001-2003. Rev Soc Bras Med Trop 2007; 40(3): 268-71. https:// doi.org/10.1590/ S0037-86822007000300003

44. Lucena LT, Aguiar LO, Bogoevich ACA, Azevedo FS, Santos ACP, Vale DBAP, et al. Dengue na Amazônia: aspectos epidemiológicos no Estado de Rondônia, Brasil, de 1999 a 2010. Rev Pan-Amaz Saúde 2011; 2(3): 19-25. https: / / doi.org/10.5123/S2176-62232011000300003

45. Borges RA, Ramos LJ, Zan RA, Meneguetti NFSP, Meneguetti DUO. Panorama epidemiológico da dengue no município de Ariquemes, Rondônia, Amazônia Ocidental, 2002 a 2011. Rev Epidemiol Control Infect 2014; 4(4): 229-32. https:// doi.org/10.17058/reci. $\mathrm{v} 4 \mathrm{i} 4.4650$

46. Vasconcelos PFC, Travassos da Rosa ES, Travassos da Rosa JFS, Freitas RB, Dégallier N, Rodrigues SG, et al. Epidemia de febre clássica de dengue causada pelo sorotipo 2 em Araguaína, Tocantins, Brasil. Rev Inst Med Trop São Paulo 1993; 35(2): 141-8. https: / / doi.org/10.1590/S0036-46651993000200005

47. Teixeira MG, Barreto ML, Guerra Z. Epidemiologia e medidas de prevenção do dengue. Inf Epidemiol SUS 1999; 8(4): 5-33. https:// doi.org/10.5123/ S0104-16731999000400002

48. Brasil. Ministério da Saúde. Secretaria de Vigilância em Saúde. Sistema Nacional de Vigilância em Saúde: relatório de situação-Alagoas. $5^{\mathrm{a}}$ ed. Brasília: Ministério da Saúde; 2011.

49. Nogueira RMR, Miagostovich MP, Schatzmayr HG, Moraes GC, Cardoso MA, Ferreira J, et al. Dengue type 2 outbreak in the South of the state of Bahia, Brazil: laboratorial and epidemiological studies. Rev Inst Med Trop São Paulo 1995; 37(6): 507-10. https: / / doi.org/10.1590/S0036-46651995000600006

50. Vasconcelos PFC, Mota K, Straatmann A, SantosTorres ASS, Travassos da Rosa APA, Tavares Neto J. Epidemia de dengue em Ipupiara e Prado, Bahia. Inquérito soro-epidemiológico. Rev Soc Bras Med Trop 2000; 33(1): 61-7. https://doi.org/10.1590/ S0037-86822000000100009

51. Teixeira MG, Costa MCN, Barreto ML, Barreto FR. Epidemiologia do dengue em Salvador-Bahia, 1995 1999. Rev Soc Bras Med Trop 2001; 34(3): 269-74. https: / / doi.org/10.1590/S0037-86822001000300007
52. Melo PRS, Reis EAG, Ciuffo IA, Góes M, Blanton RE, Reis MG. The dynamics of dengue virus serotype 3 introduction and dispersion in the state of Bahia, Brazil. Mem Inst Oswaldo Cruz 2007; 102(8): 905-12. https: / / doi.org/10.1590/S0074-02762007000800003

53. Melo MSS, Barreto FR, Costa MCN, Morato VC, Teixeira MG. Progressão da circulação do vírus do dengue no Estado da Bahia, 1994-2000. Rev Soc Bras Med Trop 2010; 43(2): 139-44. https: / / doi.org/10.1590/ S0037-86822010000200007

54. Campos GS, Pinho ACO, Brandão CJF, Bandeira AC, Sardi SI. Dengue Virus 4 (DENV-4) Re-Emerges after 30 Years in Brazil: Cocirculation of DENV-2, DENV3, and DENV-4 in Bahia. Jpn J Infect Dis 2015; 68(1): 45-9. https: / / doi.org/10.7883/yoken.JJID.2014.063

55. Souza RV, Cunha RV, Miagostovich MP, Timbó MJ, Montenegro F, Pessoa ETFP, et al. An outbreak of dengue in the State of Ceará, Brazil. Mem Inst Oswaldo Cruz 1995; 90(3): 345-46. https://doi.org/10.1590/ S0074-02761995000300006

56. Vasconcelos PFC, Menezes DB, Melo LP, Pessoa ETF, Rodrigues SG, Travassos da Rosa ES, et al. A large epidemic of dengue fever with dengue hemorrhagic cases in Ceará state, Brasil, 1994. Rev Inst Med Trop São Paulo 1995; 37(3): 253-55. https: / / doi.org/10.1590/ S0036-46651995000300012

57. Vasconcelos PFC, Lima JWO, Travassos da Rosa APA, Timbó MJ, Travassos da Rosa ES, Lima HR, et al. Epidemia de dengue em Fortaleza, Ceará: inquérito soro-epidemiológico aleatório. Rev Saúde Pública 1998; 32(5): 447-54. https: / / doi.org/10.1590/ S0034-89101998000500007

58. Cunha RV, Miagostovich MP, Petrola Z, Araújo ESM, Cortez D, Pombo V, et al. Retrospective Study on Dengue in Fortaleza, State of Ceará, Brazil. Mem Inst Oswaldo Cruz 1998; 93(2): 155-9. https://doi. org/10.1590/S0074-02761998000200003

59. Lima EP, Goulart MOF, Albuquerque MR, Victor FM, Pinto NB. Série histórica da dengue e do Aedes aegypti no Ceará. Rev Bras Prom Saúde 2013; 26(3): 340-8. https: / / doi.org/10.5020/2936

60. Cavalcanti LPG, Barreto FKA, Oliveira RMAB, Canuto IFP, Lima AAB, Lima JWO, et al. Trinta anos de dengue no Ceará: história, contribuições para ciência e desafios no cenário atual com tripla circulação de arbovírus. J Health Biol Sci 2018; 6(1): 65-2. https: / / doi.org/10.12662/2317-3076jhbs. v6i1.1415.p65-82.2018

61. Oliveira RMAB, Araújo FMC, Cavalcanti LPG. Entomological and epidemiological aspects of dengue epidemics in Fortaleza, Ceará, Brazil, 2001-2012. Epidemiol Serv Saúde 2018; 27(1): e201704414. https: / / doi.org/10.5123/s1679-49742018000100014 
62. Ramalho ILC, Araújo FMC, Cavalcanti LPG, Braga DNM, Perdigão ACB, Santos FB, et al. Dengue 4 in Ceará, Brazil: characterization of epidemiological and laboratorial aspects and causes of death during the first epidemic in the state. Mem Inst Oswaldo Cruz 2018; 113(11): e180320. https: / / doi. org/10.1590/0074-02760180320

63. Vasconcelos PFC, Lima JWO, Raposo ML, Rodrigues SG, Travassos da Rosa JFS, Amorim SMC, et al. Inquérito soro-epidemiológico na Ilha de São Luís durante epidemia de dengue no Maranhão. Rev Soc Bras Med Trop 1999; 32(2): 171-9. https:// doi. org/10.1590/S0037-86821999000200009

64. Gonçalves Neto VS, Rebêlo JMM. Aspectos epidemiológicos do dengue no Município de São Luís, Maranhão, Brasil, 1997-2002. Cad Saúde Pública 2004; 20(5): 1424-31. https://doi.org/10.1590/ S0102-311X2004000500039

65. Carvalho ACP, Portela FC, Ferro TAF, Bomfim MRQ. Epidemiologia do vírus do dengue em São Luís, Maranhão, no período de 2002 a 2012. Rev Patol Trop 2016; 45(3): 243-55. https:// doi.org/10.5216/ rpt.v45i3.43503

66. Dias Júnior JJ, Branco MRFC, Queiroz RCS, Santos AM, Moreira EPB, Silva MS. Analysis of dengue cases according to clinical severity, São Luís, Maranhão, Brazil. Rev Inst Med Trop São Paulo 2017; 59: e71. https: / / doi.org/10.1590/s1678-9946201759071

67. Montenegro D, Lacerda HR, Lira TM, Oliveira DSC, Lima AAF, Guimarães MJB, et al. Aspectos clínicos e epidemiológicos da epidemia de dengue no Recife, PE, em 2002. Rev Soc Bras Med Trop 2006; 39(1): 9-13. https: / / doi.org/10.1590/S0037-86822006000100002

68. Cordeiro MT, Schatzmayr HG, Nogueira RMR, Oliveira VF, Melo WT, Carvalho EF. Dengue and dengue hemorrhagic fever in the State of Pernambuco, 1995-2006. Rev Soc Bras Med Trop 2007; 40(6): 605-11. https: / / doi.org/10.1590/S0037-86822007000600001

69. Guedes DRD, Cordeiro MT, Melo-Santos MAV, Magalhães T, Marques E, Regis L, et al. Patient-based dengue virus surveillance in Aedes aegypti from Recife, Brazil. J Vector Borne Dis 2010; 47(2): 67-75.

70. Castro JAF, Andrade HM, Monte SJH, Silva AS, Gomes KCBL, Amaral LFB, et al. Dengue Viruses Activity in Piauí, Brazil. Mem Inst Oswaldo Cruz 2003; 98(8): 1021-3. https://doi.org/10.1590/ S0074-02762003000800007

71. Monteiro ESC, Coelho ME, Cunha IS, Cavalcante MAS, Carvalho FAA. Aspectos epidemiológicos e vetoriais da dengue na cidade de Teresina, Piauí - Brasil, 2002 a 2006. Epidemiol Serv Saúde 2009; 18(4): 365-74. https:// doi.org/10.5123/ S1679-49742009000400006
72. Figueiredo LB, Sakamoto T, Coelho LFL, Rocha ESO, Cota MMG, Ferreira GP, et al. Dengue Virus 2 American-Asian Genotype Identified during the 2006/2007 Outbreak in Piauí, Brazil Reveals a Caribbean Route of Introduction and Dissemination of Dengue Virus in Brazil. PLoS One 2014; 9(8): e 104516 . https:// doi.org/10.1371/journal. pone. 0104516

73. Cunha RV, Schatzmayr HG, Miagostovich MP, Barbosa AMA, Paiva FG, Miranda RMO, et al. Dengue epidemics in the State of Rio Grande do Norte, Brazil, in 1997. Trans Royal Soc Trop Med Hyg 1999; 93(3): 247-9. https: // doi.org/10.1016/ S0035-9203(99)90008-1

74. Barbosa IR, Araújo LF, Carlota FC, Araújo RS, Maciel IJ. Epidemiologia do dengue no Estado do Rio Grande do Norte, Brasil, 2000 a 2009. Epidemiol Serv Saúde 2012; 21(1): 149-57. https:/ / doi.org/10.5123/ S1679-49742012000100015

75. Bessa Júnior FN, Nunes RFF, Souza MA, Medeiros AC, Marinho MJM, Pereira WO. Distribuição espacial da dengue no município de Mossoró, Rio Grande do Norte, utilizando o Sistema de Informação Geográfica. Rev Bras Epidemiol 2013; 16(3): 603-10. https: / / doi. org/10.1590/S1415-790X2013000300005

76. Branco MSD, Sousa DMC, Sousa DMC, Monteiro JD, Costa DMP, Almeida Junior RF, et al. Dengue in the State of Rio Grande do Norte, Brazil, 2010-2012. Trop Med Int Health 2015; 20(12): 1707-10. https:/ / doi.org/10.1111/tmi.12612

77. Medeiros AS, Costa DMP, Branco MSD, Sousa DMC, Monteiro JD, Galvão SPM, et al. Dengue virus in Aedes aegypti and Aedes albopictus in urban areas in the state of Rio Grande do Norte, Brazil: Importance of virological and entomological surveillance. PLoS One 2018; 13(3): e0194108. https: / / doi.org/10.1371/ journal.pone.0194108

78. Brasil. Ministério da Saúde. Secretaria de Vigilância em Saúde. Sistema Nacional de Vigilância em Saúde: relatório de situação-Sergipe. $5^{\mathrm{a}}$ ed. Brasília: Ministério da Saúde; 2011.

79. Cardoso IM, Cabidelle ASA, Borges PCL, Lang CF, Calenti FG, Nogueira LO, et al. Dengue: clinical forms and risk groups in a high incidence city in the southeastern region of Brazil. Rev Soc Bras Med Trop 2011; 44(4): 1-6. https: / / doi.org/10.1590/ S0037-86822011005000044

80. Vicente CR, Pannuti CS, Urbano PR, Felix AC, Cerutti Junior C, Herbinger $\mathrm{KH}$, et al. First phylogenetic analysis of dengue virus serotype 4 circulating in Espírito Santo state, Brazil, in 2013 and 2014. Epidemiol Infect 2018; 146(1): 100-6. https:// doi.org/10.1017/ S0950268817002618 
81. Almeida MCM, Assunção RM, Proietti FA, Caiaffa WT. Dinâmica intra-urbana das epidemias de dengue em Belo Horizonte, Minas Gerais, Brasil, 1996-2002. Cad Saúde Pública 2008; 24(10): 2385-95. https: / / doi. org/10.1590/S0102-311X2008001000019

82. Cunha MCM, Caiffa WT, Oliveira CL, Kroon EG, Pessanha JEM, Lima JA, et al. Fatores associados à infecção pelo vírus do dengue no Município de Belo Horizonte, Estado de Minas Gerais, Brasil: características individuais e diferenças intra-urbanas. Epidemiol Serv Saúde 2008; 17(3): 217-30. https:// doi.org/10.5123/S1679-49742008000300007

83. Pessanha JEM, Caiaffa WT, Cecilio AB, Iani FCM, Araujo SC, Nascimento JC, et al. Cocirculation of two dengue virus serotypes in individual and pooled samples of Aedes aegypti and Aedes albopictus larvae. Rev Soc Bras Med Trop 2011; 44(1): 103-5. https:// doi.org/10.1590/S0037-86822011000100023

84. Amâncio FF, Pereira MA, Iani FCM, D’Anunciação L, Almeida JLC, Soares JAS, et al. Fatal outcome of infection by dengue 4 in a patient with thrombocytopenic purpura as a comorbid condition in brazil. Rev Inst Med Trop São Paulo 2014; 56(3): 267-70. https: / / doi. org/10.1590/ S0036-46652014000300014

85. Drumond BP, Fagundes LGS, Rocha RP, Fumagalli MJ, Araki CS, Colombo TE, et al. Phylogenetic analysis of Dengue virus 1 isolated from South Minas Gerais, Brazil. Braz J Microbiol 2016; 47(1): 251-8. https:/ / doi.org/10.1016/j.bjm.2015.11.016

86. Schatzmayr HG, Nogueira RMR, Rosa APAT. An outbreak of dengue virus at Rio de Janeiro. Mem Inst Oswaldo Cruz 1986; 81(2): 245-6. https: / / doi. org/10.1590/S0074-02761986000200019

87. Nogueira RMR, Schatzmayr HG, Miagostovich MP, Farias MFDB, Farias Filho JC. Virological study of dengue type 1 epidemic at Rio de Janeiro, Brazil. Mem Inst Oswaldo Cruz 1988; 83(2): 219-25. https: / / doi. org/10.1590/S0074-02761988000200012

88. Nogueira RMR, Miagostovich MP, Lampe E, Schatzmayr HG. Isolation of dengue virus type 2 in Rio de Janeiro. Mem Inst Oswaldo Cruz 1990; 85(2): 253. https: / / doi. org/10.1590/S0074-02761990000200022

89. Nogueira RMR, Miagostovich MP, Lampe E, Souza RW, Zagne SMO, Schatzmayr HG. Dengue epidemic in the State of Rio de Janeiro, Brazil, 1990-1991: co-circulation of dengue 1 and dengue 2 serotypes. Epidemiol Infect 1993; 111(1): 163-70. https:// doi. org/10.1017/S0950268800056788

90. Nogueira RMR, Miagostovich MP, Schatzmayr HG, Santos FB, Araújo ESM, Filippis AMB, et al. Dengue in the State of Rio de Janeiro, Brazil, 1986-1998. Mem Inst Oswaldo Cruz 1999; 94(3): 297-304. https: / / doi. org/10.1590/S0074-02761999000300004
91. Figueiredo LTM. The Brazilian flaviviruses. Microb Infect 2000; 2(13): 1643-9. https:// doi.org/10.1016/ S1286-4579(00)01320-4

92. Nogueira RMR, Miagostovich MP, Filippis AMB, Pereira MAS, Schatzmayr HG. Dengue virus type 3 in Rio de Janeiro, Brazil. Mem Inst Oswaldo Cruz 2001; 96(7): 9256. https: / doi.org/10.1590/S0074-02762001000700007

93. De Simone TS, Nogueira RMR, Araújo ESM, Guimarães FR, Santos FB, Schatzmayr HG, et al. Dengue virus surveillance: the co-circulation of DENV-1, DENV-2 and DENV-3 in the State of Rio de Janeiro, Brazil. Trans Royal Soc Trop Med Hyg 2004; 98(9): 553-62. https: / / doi.org/10.1016/j.trstmh.2003.09.003

94. Nogueira RMR, Schatzmayr HG, de Filippis AM, dos Santos FB, da Cunha RV, Coelho JO, et al. Dengue Virus type3, Brazil, 2002. Emerg Infect Dis 2005; 11(9): 1376-81. https: / / doi.org/10.3201/ eid1109.041043

95. Nogueira RMR, Eppinghaus ALF. Dengue virus type 4 arrives in the state of Rio de Janeiro: a challenge for epidemiological surveillance and control. Mem Inst Oswaldo Cruz 2011; 106(3): 255-6. https: / / doi. org/10.1590/S0074-02762011000300001

96. Castro MG, Nogueira RMR, Filippis AMB, Ferreira AA, Lima MRQ, Faria NRC, et al. Dengue virus type 4 in Niterói, Rio de Janeiro: the role of molecular techniques in laboratory diagnosis and entomological surveillance. Mem Inst Oswaldo Cruz 2012; 107(7): 9405. https: / / doi.org/10.1590/S0074-02762012000700017

97. Gibson G, Souza-Santos R, Pedro AS, Honório NA, Carvalho MS. Occurrence of severe dengue in Rio de Janeiro: an ecological study. Rev Soc Bras Med Trop 2014; 47(6): 684-91. https://doi. org/10.1590/0037-8682-0223-2014

98. Xavier DR, Magalhães MAFM, Gracie R, Reis IC, Matos VP, Barcellos C. Difusão espaço-tempo do dengue no Município do Rio de Janeiro, Brasil, no período de 2000-2013. Cad Saúde Pública 2017; 33(2): e00186615. https: / / doi.org/10.1590/0102-311x00186615

99. Lima VLC, Figueiredo LTM, Correa HRF, Leite OF, Rangel O, Vido AA, et al. Dengue: inquérito sorológico pós-epidêmico em zona urbana do Estado de São Paulo (Brasil). Rev Saúde Pública 1999; 33(6): 566-74. https:/ / doi.org/10.1590/S0034-89101999000600008

100. Bisordi I, Rocco IM, Suzuki A, Katz G, Silveira VR, Maeda AY, et al. Evaluation of dengue ns1 antigen detection for diagnosis in public health laboratories, São Paulo State, 2009. Rev Inst Med Trop São Paulo 2011; 53(6): 315-20. https: / / doi.org/10.1590/S0036-46652011000600003

101. Rocco IM, Silveira VR, Maeda AY, Silva SJS, Spenassatto C, Bisordi I, et al. First isolation of dengue 4 in the state of São Paulo, Brazil, 2011. Rev Inst Med Trop São Paulo 2012; 54(1): 49-51. https: / / doi.org/10.1590/ S0036-46652012000100009 
102. Colombo TE, Vedovello D, Mondini A, Reis AFN, Cury AAF, Oliveira FH, et al. Co-infection of dengue virus by serotypes 1 and 4 in patient from medium sized city from Brazil. Rev Inst Med Trop São Paulo 2013; 55(4): 275-81. https:// doi.org/10.1590/ S0036-46652013000400009

103. Dégallier N, Teixeira JMS, Vilarinhos PTR, Pinto SCF, Pereira RD. First isolation of dengue 1 virus from Aedes aegypti in Federal District, Brazil. Rev Soc Bras Med Trop 2000; 33(1): 95-6. https: / doi.org/10.1590/ S0037-86822000000100016

104. Teixeira JM, Chaib AJ, Silva HP, Souza JL, Molez JF, Degallier N. First autochthonous cases, caused by the Dengue-3 serotype in Federal District, Brazil. Bull Soc Pathol Exot 2006; 99(2): 85-9.

105. Feres VCR, Martelli CMT, Turchi MD, Siqueira Junior JB, Nogueira RMR, Rocha BAM, et al. Laboratory surveillance of dengue virus in Central Brazil, 19942003. J Clin Virol 2006; 37(3): 179-83. https:// doi. org/10.1016/j.jcv.2006.07.004

106. Maciel IJ, Siqueira Júnior JB, Martelli CMT. Epidemiologia e desafios no controle do dengue. Rev Patol Trop 2008; 37(2): 111-30. https:/ / doi. org/10.5216/rpt.v37i2.4998

107. Fundação Nacional de Saúde. Departamento de Operações. Coordenação de Controle de Doenças Transmitidas por Vetores. Manual de Dengue: Vigilância Epidemiológica e Atenção ao Doente. $2^{\text {a }}$ ed. Brasília: Fundação Nacional de Saúde; 1996.

108. Machiner F, Rodrigues DJ, Andrade EA. Distribuição de dengue no norte de Mato Grosso, Brasil, 2001-2005. Cad Saúde Coletiva 2009; 17(3): 627-40.

109.Zuchi N, Heinen LBS, Santos MAM, Pereira FC, Slhessarenko RD. Molecular detection of Mayaro virus during a dengue outbreak in the state of Mato Grosso, Central-West Brazil. Mem Inst Oswaldo Cruz 2014; 109(6): 820-3. https:/ / doi.org/10.1590/0074-0276140108

110. Cruz LCTA, Serra OP, Leal-Santos FA, Ribeiro ALM, Slhessarenko RD, Santos MA. Natural transovarial transmission of dengue virus 4 in Aedes aegypti from Cuiabá, State of Mato Grosso, Brazil. Rev Soc Bras Med Trop 2015; 48(1): 18-25. https:// doi. org/10.1590/0037-8682-0264-2014

111.Heinen LBS, Zuchi N, Cardoso BF, Santos MAM, Nogueira ML, Dezengrini-Slhessarenko R. Dengue outbreak in Mato Grosso State, Midwestern Brazil. Rev Inst Med Trop São Paulo 2015; 57(6): 489-96. https: / / doi.org/10.1590/S0036-46652015000600005

112.Serra OPS, Cardoso BF, Ribeiro ALM, Santos FAL, Slhessarenko RD. Mayaro virus and dengue virus 1 and 4 natural infection in culicids from Cuiabá, state of Mato Grosso, Brazil. Mem Inst Oswaldo Cruz 2016; 111(1): 20-9. https: / / doi.org/10.1590/0074-02760150270
113. Rocco IM, Barbosa ML, Kanomata EHN. Simultaneous infection with dengue 1 and 2 in a Brazilian patient. Rev Inst Med Trop São Paulo 1998; 40(3): 151-4. https: / / doi.org/10.1590/S0036-46651998000300004

114. Uehara PM, Cunha RV, Pereira GROL, Oliveira PA. Envolvimentohepáticoempacientescomdenguehemorrágico: manifestação rara? Rev Soc Bras Med Trop 2006; 39(6): 544-7. https://doi.org/10.1590/S0037-86822006000600006

115. Bertolacci-Rocha LG, Cunha RV, Lichs GGC, Dal Fabbro MMFJ, Motta-Castro ARC. Introduction of the dengue virus type 4 in the State of Mato Grosso do Sul, Brazil. Cad Saúde Pública 2014; 30(8): 178992. https: / / doi.org/10.1590/0102-311X00003914

116. Faria NRC, Solorzano VEF, Nogueira RMR, ChouinCarneiro T, Nunes PCG, Simões JBS, et al. Dengue epidemics in two distinct periods reveal distinct epidemiological, laboratorial and clinical aspects in a same scenario: analysis of the 2010 and 2013 epidemics in Mato Grosso do Sul, Brazil. Trans Royal Soc Trop Med Hyg 2016; 110(4): 228-36. https: / / doi. org $/ 10.1093 /$ trstmh $/$ trw013

117. Oliveira MMF. Condicionantes sócio-ambientais urbanos da incidência da denguena cidade de Londrina/PR[dissertation]. Paraná: Universidade Federal do Paraná; 2006.

118. Kuczera D, Bavia L, Mosimann ALP, Koishi AC, Mazzarotto GACA, Aoki MN, et al. Isolation of dengue virus serotype 4 genotype II from a patient with high viral load and a mixed Th1/Th17 inflammatory cytokine profile in South Brazil. Virol J 2016; 13: 93. https: / / doi.org/10.1186/s12985-016-0548-9

119. Souza RP, Rocco IM, Maeda AY, Spenassatto C, Bisordi I, Suzuki A, et al. Dengue Virus Type 4 Phylogenetics in Brazil 2011: Looking beyond the Veil. PLoS Negl Trop Dis 2011; 5(12): e1439. https:// doi.org/10.1371/journal.pntd.0001439

120. Tumioto GL, Gregianini TS, Dambros BP, Cestari BC, Nunes ZMA, Veiga ABG. Laboratory Surveillance of Dengue in Rio Grande do Sul, Brazil, from 2007 to 2013. PLoS One 2014; 9(8): e104394. https: / / doi. org/10.1371/journal.pone.0104394

121. Gregianini TS, Tumioto-Giannini GL, Favreto C, Plentz LC, Ikuta N, Veiga ABG. Dengue in Rio Grande do Sul, Brazil: 2014 to 2016. Rev Med Virol 2018; 28(1): e1960. https: / / doi.org/10.1002/rmv.1960

122. Brasil. Ministério da Saúde. Dengue - Distribuição de casos confirmados de 1980 a 1988, por Unidade Federada, Brasil [Internet]. Brasil: Ministério da Saúde; 1997 [cited on Mar. 19, 2020]. Available from: http:/ / scielo.iec.gov.br/pdf/iesus/v6n1/p045.pdf

123. Brasil. Ministério da Saúde. Dengue - Distribuição de casos confirmados de 1989 a 1996, por Unidade Federada, Brasil [Internet]. Brasil: Ministério da Saúde; 1997 [cited on Mar. 19, 2020]. Available from: http: / / scielo.iec.gov.br/pdf/iesus/v6n1/p046.pdf 
124. Brasil. Ministério da Saúde. Casos de Dengue. Brasil, Grandes Regiões e Unidades Federadas, 1990 a 2016 [Internet]. Brasil: Ministério da Saúde; 2017 [cited on Mar. 21, 2020]. Available from: http:/ / portalarquivos. saude.gov.br/images/pdf/2017/fevereiro/10/Dengueclassica-ate-2016.pdf

125. Siqueira JB, Martelli CMT, Coelho GE, Simplício ACR, Hatch DL. Dengue and Dengue Hemorrhagic Fever, Brazil, 1981-2002. Emerg Infect Dis 2005; 11(1): 48-53. https: / / doi.org/10.3201/ eid1101.031091

126. Glasser CM, de Castro Gomes A. Infestation of S. Paulo State, Brazil, by Aedes aegypti and Aedes albopictus. Rev Saúde Pública 2000; 34(6): 570-7. https:// doi. org/10.1590/S0034-89102000000600002

127. Cavalcanti LPG, Oliveira RMAB, Alencar CH. Changes in infestation sites of female Aedes aegypt in Northeast Brazil. Rev Soc Bras Med Trop 2016; 49(4): 498-501. https: / / doi.org/10.1590/0037-8682-0044-2016

128. Rivas AV, Defante R, Delai RM, Rios JA, Britto AS, Leandro AS, et al. Building Infestation Index for Aedes aegypti and occurrence of dengue fever in the municipality of Foz do Iguaçu, Paraná, Brazil, from 2001 to 2016. Rev Soc Bras Med Trop 2018; 51(1): 71-6. https: / doi.org/10.1590/0037-8682-0228-2017
129.Donalisio MR, Freitas ARR, Zuben APBV. Arboviruses emerging in Brazil: challenges for clinic and implications for public health. Rev Saúde Pública 2017; 51: 30. https:// doi.org/10.1590/s1518-8787.2017051006889

130. Viana DV, Ignotti E. A ocorrência da dengue e variações meteorológicas no Brasil: revisão sistemática. Rev Bras Epidemiol 2013; 16(2): 240-56. https:// doi.org/10.1590/ S1415-790X2013000200002

131. Teixeira MG, Costa MCN, Barreto ML, Mota E. Dengue and dengue hemorrhagic fever epidemics in Brazil: what research is needed based on trends, surveillance, and control experiences? Cad Saúde Pública 2005; 21(5): 1307-15. https:/ / doi.org/10.1590/ S0102-311X2005000500002

Received on: 08/06/2020

Revised on: 09/28/2020

Accepted on: 11/09/2020

Authors' contributions: J.M.T.B., M.C., and D.S.B. participated in the study concept and design.J.M.T.B. and S.C.S. performed the analysis of the data. J.M.T.B., S.C.S., P.L.T., M.C., and D.S.B. participated in interpretation of the data and critical revisions of the manuscript. 